\title{
A New Oxyprenyl Coumarin and Highly Methylated Flavones from the Exudate of Ozothamnus lycopodioides (Asteraceae)
}

\author{
Angel Rumbero ${ }^{\mathrm{a}}$, Fco. Javier Arriaga-Giner ${ }^{\mathrm{b}}$ and Eckhard Wollenweber ${ }^{\mathrm{c}, *}$ \\ a Departamento de Química Orgánica, Universidad Autónoma de Madrid, Cantoblanco, \\ E-28049 Madrid, Spain \\ b Tabacalera S. A.; Centro I+D, c/ Embajadores 51, E-28012 Madrid, Spain \\ c Institut für Botanik der Technischen Universität, Schnittspahnstrasse 3, D-64287 Darm- \\ stadt, Germany. Fax: 06151/166878. E-mail: Wollenweber@bio.tu-darmstadt.de \\ * Author for correspondance and reprint requests \\ Z. Naturforsch. 55c, 1-4 (2000); received November 5, 1999 \\ Ozothamnus lycopodioides, Asteraceae, Leaf and Stem Exudate, Flavones, \\ New Oxyprenyl Coumarin \\ A new oxyprenyl coumarin was isolated from the lipophilic exudate of Ozothamnus lyco- \\ podioides. Its structure was established as 7-(3,3'-dimethylallyloxy)-5-hydroxy-6-methoxy- \\ coumarin from its UV, MS and NMR spectral data, especially two dimensional experiments. \\ In addition to six earlier reported flavonols, we found four highly substituted flavones, includ- \\ ing two rare methylenedioxyflavones.
}

The genus Ozothamnus (Asteraceae) comprises some 50 species, native to Australia, New Zealand and New Caledonia (Bremer, 1994). A previous paper dealt with rare flavonoids occurring in the leaf and stem exudates of two Odixia and eleven Ozothamnus species from Australia. O. lycopodioides was reported to exhibit six flavonols, namely herbacetin-3,7,8,4'-tetramethyl ether, quercetin-3 methyl ether, quercetin-3,7-dimethyl ether, quercetagetin-3,6-dimethyl ether, gossypetin-3,7,8-trimethyl ether and gossypetin-3,7,8,3',4'-pentamethyl ether (Wollenweber et al., 1997). In addition, we now identified four flavones and a new oxyprenylated coumarin.

\section{Material and Methods}

Branches of Ozothamnus lycopodioides were collected at Black Bridge Gulli, Tasmania ( $42^{\circ}$ $34^{\prime} \mathrm{S} 147^{\circ} 49^{\prime} \mathrm{E}$ ) on 26. Jan. 1989. A voucher (Davis 1259) is kept at the Herbarium Australiense in Canberra, Australia (CANB). Air-dried plant material was briefly rinsed with acetone to dissolve the lipophilic exudate. The concentrated solution was then subjected to column chromatography on Sephadex LH-20, eluted with methanol, to separate the phenolic fractions from the predominant terpenoids. Fractions containing flavonoid aglycones were concentrated and the residue (3.1 g) was further chromatographed on "flash" silica-gel using the binary mixture ethyl acetate hexane (3:1 v/v), furnishing 1 (165 mg), 2 (52 mg), 3 (210 mg), 4 (360 mg) and 5 (23 mg).

M.p.'s are uncorrected. ${ }^{1} \mathrm{H}$ NMR: $300 \mathrm{MHz}$, TMS as int. Standard. ${ }^{13} \mathrm{C}$ NMR : $75.5 \mathrm{MHz}$, solvent as internal standard. 2D NMR experiments were performed using standard Bruker pulse sequences. MS: EI (70 eV), VG AutoSpec. IR: $\mathrm{KBr}$, Bruker Vector 22. UV: $\mathrm{MeOH}$, Hewlett Packard 8453.

5,6,7,8-tetramethoxy-3', 4'-methylendioxyflavone (1). Colourless crystals $(\mathrm{MeOH}), \mathrm{mp} .169-170{ }^{\circ} \mathrm{C}$. TLC $\left(\mathrm{SiO}_{2} 60\right)$ : Rf 0.55 (AcOEt-hexane, 3:1 v/v). IR, UV and ${ }^{1} \mathrm{H}$ NMR as literature (Ngo Le-Van et al., 1979). ${ }^{13} \mathrm{C} \mathrm{NMR}\left(\mathrm{CDCl}_{3}\right), \delta$ ppm: $61.50\left(\mathrm{CH}_{3}\right)$, $61.66\left(\mathrm{CH}_{3}\right), 61.89\left(\mathrm{CH}_{3}\right), 62.10\left(\mathrm{CH}_{3}\right), 101.79$ $\left(\mathrm{CH}_{2}\right), 105.89(\mathrm{CH}), 106.92(\mathrm{CH}), 108.65(\mathrm{CH})$, 114.70 (C), $120.94(\mathrm{CH}), 125.36$ (C), 137.94 (C), 143.98 (C), 147.50 (C), 148.20 (C), 148.34 (C), 150.35 (C), 151.29 (C), 160.64 (C), 177.06 (C).

5,6,7,8,5' -pentamethoxy-3', 4' -methylendioxyflavone (2). Yellow crystals $(\mathrm{MeOH}), \mathrm{mp} 185-$ $187^{\circ} \mathrm{C}$. TLC $\left(\mathrm{SiO}_{2} 60\right)$ : Rf 0.50 (AcOEt-hexane, $3: 1 \mathrm{v} / \mathrm{v})$. IR, UV, ${ }^{1} \mathrm{H}$ NMR as literature (Ngo LeVan et al., 1979). ${ }^{13} \mathrm{C} \mathrm{NMR}\left(\mathrm{CDCl}_{3}\right), \delta$ ppm: 56.70 $\left(\mathrm{CH}_{3}\right), 61.63\left(\mathrm{CH}_{3}\right), 61.78\left(\mathrm{CH}_{3}\right), 61.94\left(\mathrm{CH}_{3}\right)$, $62.22\left(\mathrm{CH}_{3}\right), 61.63\left(\mathrm{CH}_{3}\right), 61.78\left(\mathrm{CH}_{3}\right), 61.94$ $\left(\mathrm{CH}_{3}\right), 62.22\left(\mathrm{CH}_{3}\right), 100.43(\mathrm{CH}), 102.27\left(\mathrm{CH}_{2}\right)$, $106.53(\mathrm{CH}), 107.31(\mathrm{CH}), 114.82(\mathrm{C}), 125.89(\mathrm{C})$, 137.99 (C), 138.27 (C), 143.88 (C), 144.13 (C), 
147.61 (C), 148.36 (C), 149.54 (C), 151.46 (C), 160.61 (C), 177.20 (C).

$5,6,7,8,3^{\prime}, 4^{\prime}$-hexamethoxyflavone (3). Yellow crystals, mp. $130-131{ }^{\circ} \mathrm{C}(\mathrm{MeOH})$. TLC $\left(\mathrm{SiO}_{2} 60\right)$ : Rf 0.31 (AcOEt-hexane $3: 1 \mathrm{v} / \mathrm{v}$ ). IR, UV, ${ }^{1} \mathrm{H}$ NMR as literature (Ngo Le-Van et al., 1979). ${ }^{13} \mathrm{C}$ NMR (CDCl3), $\delta$ ppm: $55.64\left(\mathrm{CH}_{3}\right), 55.78\left(\mathrm{CH}_{3}\right), 61.35$ $\left(\mathrm{CH}_{3}\right), 61.50\left(\mathrm{CH}_{3}\right), 61.65\left(\mathrm{CH}_{3}\right), 61.94\left(\mathrm{CH}_{3}\right)$, $106.50(\mathrm{CH}), 108.24(\mathrm{CH}), 110.97(\mathrm{CH}), 114.52$ (C), 119.65 (C), 126.50 (C), $137.71(\mathrm{C}), 143.76(\mathrm{C})$, 147.39 (C), 148.06 (C), 148.97 (C), 151.11 (C), 151.63 (C), 160.69 (C), 176.95 (C).

$5,6,7,8,3^{\prime}, 4^{\prime}, 5^{\prime}$-heptamethoxyflavone (4). Yellow crystals, mp $104-105^{\circ} \mathrm{C}$. TLC $\left(\mathrm{SiO}_{2} 60\right)$ : Rf 0.40 (AcOEt-hexane 3:1 v/v). IR, UV, ${ }^{1} \mathrm{H}$ NMR as literature (Ngo Le-Van et al., 1979). ${ }^{13} \mathrm{C}$ NMR $\left(\mathrm{CDCl}_{3}\right), \delta$ ppm: $56.02\left(2 \mathrm{xCH}_{3}\right), 60.81 \cdot\left(\mathrm{CH}_{3}\right)$, $61.31\left(\mathrm{CH}_{3}\right), 61.49\left(\mathrm{CH}_{3}\right), 61.60\left(\mathrm{CH}_{3}\right), 61.71$ $\left(\mathrm{CH}_{3}\right), 62.05\left(\mathrm{CH}_{3}\right), 103.04(2 \times \mathrm{CH}), 107.41(\mathrm{CH})$, 114.63 (C), 126.48 (C), 137.80 (C), 140.85 (C), 143.96 (C), 147.52 (C), 148.21 (C), 151.35 (C), 153.38 (2xC), 160.55 (C), 177.07 (C).

7-(3,3'-dimethylallyloxi)-5-hydroxy-6-methoxycoumarin (5). Yellow crystals, mp $143-145^{\circ} \mathrm{C}$. TLC $\left(\mathrm{SiO}_{2} 60\right)$ : Rf 0.82 (AcOEt-hexane 3:1 v/v). UV (MeOH) $\lambda_{\max } \mathrm{nm}(\log \varepsilon): 210$ (4.47), 325 (4.10); IR $v_{\max } \mathrm{cm}^{-1}: 3298(\mathrm{OH}), 1703(\mathrm{C}=\mathrm{O})$, $1624(\mathrm{C}=\mathrm{C})$. MS $(70 \mathrm{eV}) \mathrm{m} / z$ (rel. int.), $276[\mathrm{M}+]$ (9), 208 (100), 193 (70), 165 (8), 137 (7), 95 (12),
69 (75). For ${ }^{1} \mathrm{H}$ NMR $\left(\mathrm{CDCl}_{3}\right.$ and $\left.\mathrm{C}_{6} \mathrm{D}_{6}\right)$ and ${ }^{13} \mathrm{C}$ NMR data see Table I.

\section{Results and Discussion}

The lipophilic exudate produced by aerial parts of Ozothamnus lycopodioides was shown previously to contain six flavonol aglycones. From remaining fractions we now isolated the methylenedioxyflavones linderoflavone B (lucidin dimethyl ether) (1), eupalestin (2), nobiletin (3), and 5'-methoxynobiletin (4). Their structures were assigned by comparison with spectral data described in literature (1: Lee et al., 1965; 2: Ngo Le-Van et al., 1979; 3: Tseng, 1938; 4: Ngo Le-Van et al., 1979).

Compound $\mathbf{5}$ was obtained as a yellow solid. The EI mass spectrum of $\mathbf{5}$ showed a weak $\mathrm{M}^{+}$ion at $\mathrm{m} / \mathrm{z} 276$, which by accurate mass measurent corresponded to a molecular formula of $\mathrm{C}_{15} \mathrm{H}_{16} \mathrm{O}_{5}$. Both, ${ }^{1} \mathrm{H}$ NMR and ${ }^{13} \mathrm{C}$ NMR spectra, contained too many signals to fit the above mentioned formula.

In the ${ }^{1} \mathrm{H}$ NMR spectrum of 5 (recorded in $\left.\mathrm{CDCl}_{3}\right)$, the doublets at $\delta 6.19$ and $7.96(J=9.6$ $\mathrm{Hz}$ ) could be attributed to $\mathrm{H}-3$ and $\mathrm{H}-4$ and the low-field nature of the chemical shift of $\mathrm{H}-4$ suggested the presence of an oxygenated group at C5 (Murray et al., 1982). A multiplet at $\delta 5.46(1 \mathrm{H})$, a doublet at $\delta 4.60(2 \mathrm{H}, J=6.6 \mathrm{~Hz})$ and two sin-

Table I. ${ }^{1} \mathrm{H}$ and ${ }^{13} \mathrm{C}$ NMR assignments and ${ }^{1} \mathrm{H}-{ }^{13} \mathrm{C}$ long-range correlations of 5 by $\mathrm{HMBC}$, and ${ }^{1} \mathrm{H}$ and ${ }^{13} \mathrm{C}$ NMR spectral data of 6 .

\begin{tabular}{|c|c|c|c|c|c|c|c|}
\hline \multirow[b]{2}{*}{ Position } & \multirow[b]{2}{*}{${ }^{1} \mathrm{H}\left(\mathrm{CDCl}_{3}\right)$} & \multirow[b]{2}{*}{${ }^{1} \mathrm{H}\left(\mathrm{C}_{6} \mathrm{D}_{6}\right)$} & \multicolumn{2}{|l|}{5} & \multirow[b]{2}{*}{$\begin{array}{l}\text { Cross-peaks in } \\
\text { HMBC spectrum }\end{array}$} & \multicolumn{2}{|c|}{6} \\
\hline & & & $\Delta^{*}$ & ${ }^{13} \mathrm{C}\left(\mathrm{CDCl}_{3}\right)$ & & ${ }^{1} \mathrm{H}\left(\mathrm{CDCl}_{3}\right)$ & ${ }^{13} \mathrm{C}\left(\mathrm{CDCl}_{3}\right)$ \\
\hline 2 & & & & 161.59 & & & 161.3 \\
\hline 3 & $6.19(\mathrm{~d}, 9.6)$ & $5.73(\mathrm{~d}, 9.6)$ & 0.46 & 111.38 & $102.41(10), 161.59(2)$ & $6.23(d)$ & 111.6 \\
\hline 4 & $7.96(\mathrm{~d}, 9.6)$ & $7.36(\mathrm{~d}, 9.6)$ & 0.60 & 138.71 & $\begin{array}{l}93.25(8), 145.69(5) \\
151.57(9), 161.59(2)\end{array}$ & $7.97(\mathrm{~d})$ & 138.8 \\
\hline 5 & & & & 145.69 & & & 146.1 \\
\hline 6 & & & & 131.81 & & & 131.8 \\
\hline 7 & & & & 154.84 & & & 154.7 \\
\hline 8 & $6.42(\mathrm{~s})$ & $6.00(\mathrm{~s})$ & 0.42 & 93.25 & $\begin{array}{c}102.41(10), 131.80(6) \\
151.57(9), 154.84(7)\end{array}$ & $6.43(\mathrm{~s})$ & 93.0 \\
\hline 9 & & & & 151.57 & & & 151.6 \\
\hline 10 & & & & 102.41 & & & 103.2 \\
\hline $1^{\prime}$ & 4.60 (br d, 6.6) & 3.91 (br d, 6.6) & 0.69 & 65.93 & $\begin{array}{c}118.61\left(2^{\prime}\right), 139.02 \\
\left(3^{\prime}\right), 154.84(7)\end{array}$ & $4.35(\mathrm{dd})$ & 70.5 \\
\hline $3^{\prime}$ & & & & 139.02 & & & 71.9 \\
\hline $\mathrm{CH}_{3}-3^{\prime}$ & $1.75(\mathrm{~d}, 0.8)$ & 1.21 (br s) & & 18.29 & $18.29,25.74$ & $1.35(\mathrm{~s})$ & 25.1 \\
\hline & $1.79(\mathrm{~d}, 1.0)$ & 1.35 (br s) & & 25.74 & $118.61\left(2^{\prime}\right) 139.02\left(3^{\prime}\right)$ & $1.39(\mathrm{~s})$ & 26.3 \\
\hline $\mathrm{CH}_{3}-\mathrm{O}$ & $3.88(\mathrm{~s})$ & $3.28(\mathrm{~s})$ & 0.60 & 61.20 & $131.81(6)$ & $4.07(\mathrm{~s})$ & 61.5 \\
\hline
\end{tabular}

$*: \Delta=\delta_{\mathrm{CDCl} 3}-\delta_{\mathrm{C} 6 \mathrm{D} 6}$. 
<smiles>[R]c1cc(-c2cc(=O)c3c(OC)c(OC)c(OC)c(OC)c3o2)cc2c1OCO2</smiles><smiles>COc1c(OC[I-]C=C(C)C)cc2oc(=O)ccc2c1O</smiles>

glets at $\delta 1.75$ and 1.79 (3H each) indicated the presence of a 3,3'-dimethylallyloxy side-chain, which was confirmed by the ${ }^{13} \mathrm{C}$ NMR spectrum. The methoxyl singlet at $\delta 3.88$ and the presence of a singlet at $\delta 6.42$ in the ${ }^{1} \mathrm{H}$ NMR spectrum showed that compound $\mathbf{5}$ is a coumarin with three oxygenated substituents in the aromatic region.

The assignment of the hydroxy, methoxy and dimethylallyloxy moieties was carried out using the bidimensional experiments: HMBC and NOESY spectra. The HMBC spectrum showed the following connectivities: a) the protons of the methoxyl group at $\delta 3.88$ showed ${ }^{3} J$ to $\delta 131.81$; b) the protons of the methylene group of the prenylated moietie at $\delta 4.60$ showed ${ }^{3} J$ coupling to carbon of the aromatic ring at $\delta 154.84$ and to carbon of the olefinic group at $\delta 139.02$; c) $\mathrm{H}-4$ at $\delta 7.96$ showing ${ }^{3} \mathrm{~J}$ couplings to carbons of the aromatic nucleus resonating at $\delta 145.69$ and $\delta 151.57$, and to carbon at $\delta 161.59$ (CO). This allows the assignment of the C-5 hydroxy substituent and confirms that the chemical shift of C-5 may be either $\delta 145.69$ or $\delta$ 151.57. Additionally, the HMBC spectrum showed ${ }^{3} J$ couplings between the proton $\mathrm{H}-3$ at $\delta 6.19$ and the carbon of the aromatic ring at $\delta 102.41$; also the aromatic proton at $\delta 6.41$ showed ${ }^{3} J$ coupling to carbon at $\delta 102.41$, indicating that the proton of the aromatic nucleus is at the position C-6 or C-8.<smiles>[R]c1cc(-c2cc(=O)c3c(OC)c(OC)c(OC)c(OC)c3o2)cc(OC)c1OC</smiles><smiles>COc1c(OCC(O)C(C)(C)O)cc2oc(=O)ccc2c1O</smiles>

The assignment of the positions of the oxyprenyl and methoxy groups was again based on NOESY experiment, this spectrum showing bidirectional connectivities between the aromatic proton at $\delta$ 6.41 and the protons of the methylene oxyprenylated at $\delta 4.60$. It showed no correlation with the protons of the methoxyl group.

The study of HMBC and NOESY spectra allowed the assignment of two plausible structures for compound 5: a) 7-(3,3'-dimethylallyloxy)-5-hydroxy-8-methoxy-coumarin or b) 7-(3,3'-dimethylallyloxy)-5-hydroxy-6-methoxy-coumarin. The final structural decision was made by means of a solvent shift method with $\mathrm{CDCl}_{3}$ and benzene- $\mathrm{d}_{6}$ as the solvents, and the $2 \mathrm{D}{ }^{1} \mathrm{H}-{ }^{1} \mathrm{H}$ COSY experiment.

Solvent induced shifts in benzene- $\mathrm{d}_{6}$ relative to $\mathrm{CDCl}_{3}\left(\Delta=\delta_{\mathrm{CDCl} 3}-\delta_{\mathrm{C} 6 \mathrm{D} 6}\right)$ have been measured and used to determine the position of methoxyl groups in coumarins (González et al., 1973; Grigg et al., 1966). Methoxyl groups located at C-8 show only minor changes $(\Delta \delta \equiv 0.1-0.2 \mathrm{ppm})$ and are readily distinguished from other isomers (Dean et al., 1978). In compound $\mathbf{5}$ this effect is large for the methoxy group $(\Delta \delta=0.60 \mathrm{ppm})$, similar to the effect of a methoxyl group in C-6 of capensin (García et al., 1988); hence the methoxyy group has to be assigned to position C-6 of the coumarin 5. Additionally, the $2 \mathrm{D}{ }^{1} \mathrm{H}-{ }^{1} \mathrm{H}$ COSY spectrum 
showed an interaction between $\mathrm{H}-4(\delta$ 7.96) and the aromatic proton at $\delta 6.42$, this being assigned to $\mathrm{H}-8$, since the literature reports a W-like coupling between $\mathrm{H}-4$ and $\mathrm{H}-8$ in coumarins (Murray et al., 1982; Rashid et al., 1992; Vilegas et al., 1995).

All these data are compatible with the structure of 7-(3,3'-dimethylallyloxy)-5-hydroxy-6-methoxycoumarin 5. The ${ }^{1} \mathrm{H}$ NMR and ${ }^{13} \mathrm{C}$ NMR spectral data of compound $\mathbf{5}$ agree with those previously described for compound 6 (Vilegas et al., 1995), except for the signals corresponding to the prenyl group (Table I).

Linderoflavone B (1), first reported from Lindera lucida (Lee et al., 1965), was later found in Ageratum (Wollenweber et al., 1994) and in Eupatorium (Ngo Le-Van et al., 1979). Eupalestin (2), first known from Eupatorium coelestinum (Ngo Le-Van et al., 1979), was also found in Ageratum species (Wollenweber et al., 1994). Nobiletin (3) is a well-known constituent of Citrus fruit peel (Tseng, 1938), but also known to occur e.g. in the

Bremer K. (1994), Asteraceae: Cladistics and Classification. Timber Press, Portland.

Dean F. M., Costa A. M. B. S. R. C. S., Harborne J. B. and Smith D. M. (1978), Leptodactylone, a yellow coumarin from Leptodactylon and Linanthus species. Phytochemistry 17, 505-509.

García E. E. and Guerreiro E. (1988), Sesquiterpene lactones from Gochnatia palosanto and Coumarins from G. Argentina. Phytochemistry 27, 288-290.

González A. G., Breton J. L., López Dorta H., Martínez In/1guez, M. A. and Rodríguez Luis F. (1973), Aplicación de la Resonancia Magnética Nuclear en el estudio de estructuras de cumarinas. Ann. Quim. 69, 1013-1029.

González A. G., Aguiar Z. E., Grillo T. A., Luis J. G., Rivera A. and Calle J. (1991), Methoxyflavones from Ageratum conyzoides. Phytochemistry 30, 1269-1271.

Grigg R., Knight J. A. and Roffey P. (1966), NMR solvent shifts and structure elucidation in coumarins. Tetrahedron 22, 3301-3304.

Herz W. and Kulanthaivel P. (1982), Flavones from Eupatorium leucolepis. Phytochemistry 21, 2363-2366.

Lee H. H. and Tan C. H. (1965), Synthesis of Flavones from Lindera lucida. J. Chem. Soc. 2743-2749.

Martínez-Vázquez M., Rojas-Amaro A. and Joseph-Nathan P. (1988), Three flavonoids from Ageratum tomentosum var. bracteatum. Phytochemistry 27, 3706-3707.
Asteraceae Ageratum conyzoides (González et al., 1991), Eupatorium leucolepis (Herz et al., 1982) and Viguiera rosei (Wollenweber et al., 1995). 5'methoxynobiletin (4) was earlier reported from the Asteraceae Ageratum conyzoides (González et al., 1991), Ageratum tomentosum (Vázquez et al., 1988), Conoclinium greggii (Martínez-Vázquez et al., 1993) and Eupatorium coelestinum (Ngo LeVan et al., 1979). To our knowledge this is the first time that methylenedioxyflavones are definitively reported as constituents of lipophilic exudates. We assume, however, that earlier authors did not care for the localization of these compounds, that they may also be accumulated externally on the plant species cited above (with the exception of Citrus peel, where they are localized in oil cavities).

\section{Acknowledgements}

The authors wish to thank Dr Chris Puttock (Canberra) for the plant material, and Mrs Marion Dörr (Darmstadt) for technical assistance.

Martínez-Vázquez M., Vázquez García H. M., Toscano R. A. and Pérez G. E. (1993), Methylated flavones from Conoclinium greggii. J. Nat. Prod. 56, 1410-1413.

Murray R. D. H., Mendez J. and Brown S. A. (1982), The Natural Coumarins, John Wiley and Sons, New York.

Ngo Le-Van and Thi Vam Cuong Pham. (1979), Two new flavones from Eupatorium coelestinum. Phytochemistry 18, 1859-1859-1861.

Rashid M. A., Armstrong J. A., Gray A. I. and Waterman P. G. (1992). Alkaloids, Flavonols and Coumarins from Drummondita hassellii and D. calida. Phytochemistry 31, 1265-1269.

Tseng K. F. (1938), Nobiletin. J. Chem. Soc. 1003-1004.

Vilegas W., Boralle N., Cabrera A., Bernardi A. C., Pozetti G. L. and Arantes S. F. (1995), Coumarins and a Flavonoid from Pterocaulon Alopecuroides. Phytochemistry 38, 1017-1019.

Wollenweber E. (1994), In: The Flavonoids - Advances in Research since 1986 (J. B. Harborne, ed.). Chapman and Hall, London.

Wollenweber E., Dörr M., Roitman J. N. and Schilling E. (1995), External flavonoids of three species of $V i$ guiera, section Hypargyrea (Asteraceae). Z. Naturforsch. 50c, 588-590.

Wollenweber E., Dörr M., Beyer M., Roitman J. N. and Puttock C. F. (1997), Rare flavonoids from Odixia and Ozothamnus sp. (Asteraceae, Gnaphalieae). Z. Naturforsch. 52c, 571-576. 